\title{
The Effect of Delayed Ensiling and Application of a Propionic Acid-Based Additive on the Fermentation of Barley Silage ${ }^{1,2}$
}

\author{
J. A. Mills ${ }^{3}$ and L. Kung, Jr. \\ Delaware Agricultural Experiment Station \\ Department of Animal \& Food Sciences \\ College of Agriculture and Natural Resources \\ University of Delaware \\ Newark, DE 19717-1303
}

\begin{abstract}
Prolonged exposure to air can adversely affect the silage fermentation process. To investigate a possible method to overcome this problem, we determined if a buffered propionic acid-based additive, applied to chopped, whole-plant barley exposed to air before ensiling, would affect the subsequent fermentation. Wilted forage was chopped and treated with nothing, or with $0.1 \%$ (wt/wt wet forage) of a buffered propionic acidbased additive and ensiled immediately in quadruplicate 20-L laboratory silos. Portions of the chopped forage, untreated and treated, were left in loose piles in a barn for $24 \mathrm{~h}$ before ensiling. Another portion of the untreated silage exposed to air for $24 \mathrm{~h}$ was also treated with $0.1 \%$ of the additive just before ensiling. Prolonged exposure to air before ensiling increased the numbers of yeasts on forages by more than 1000 -fold. The concentrations of water-soluble carbohydrates decreased by more than 50\%; the ammonia-N concentrations increased $40 \%$, and $\mathrm{pH}$ increased by more than 1 unit as a result of exposure to air. These changes were less in forage that was treated with the additive at chopping. After $60 \mathrm{~d}$, silages of forages that were exposed to air before ensiling had a higher $\mathrm{pH}$, higher concentrations of ammonia-N and butyric acid, and lower concentrations of lactic and acetic acids than silages of forage that had been ensiled immediately after harvest. In situ DM digestibility was lowest in untreated silages that had been exposed to air before ensiling. In contrast, treatment with the additive, applied before or after exposure to air, prevented the reduction in in vitro digestion.
\end{abstract}

Received July 3, 2001.

Accepted October 11, 2001

Corresponding author: L. Kung, Jr.; e-mail: lkung@udel.edu.

${ }^{1}$ Published as Miscellaneous Paper Number 1703 of the Delaware Agricultural Experiment Station.

${ }^{2}$ This study was partially supported by Kemin Industries, Inc., Des Moines, IA.

${ }^{3}$ Current address: Department of Animal Science, University of Nebraska, Lincoln, NE 68503.
(Key words: silage, ensiling, propionic acid)

Abbreviation key: $\mathbf{C}=$ chopped barley immediately ensiled, CDF = chopped barley forage exposed to air for $24 \mathrm{~h}$ before ensiling, $\mathbf{K I}=$ chopped barley forage treated with an additive and immediately ensiled, KIDO $=$ chopped barley forage treated with an additive and exposed to air for 24 before ensiling, KI-D24 = chopped barley forage treated exposed to air for $24 \mathrm{~h}$, then treated with an additive just before ensiling, WSC $=$ water-soluble carbohydrates.

\section{INTRODUCTION}

After chopping, the presence of air in a forage mass delays the onset of fermentation and encourages the growth of undesirable microbes, which results in negative effects on the ensuing fermentation (McDonald et al., 1991). To eliminate air from the forage mass, forages should be packed rapidly and packed tightly into silos. However, poor management decisions, such as leaving chopped forage in wagons or piles, can result in substantial delays in filling silos; thus, forages may be exposed to air for prolonged periods of time. In addition, large bunk or trench silos sometimes require weeks to fill, which exposes forages to excessive amounts of air.

Air is also detrimental during storage and feedout because it stimulates the growth of yeasts that metabolize lactic acid, which results in loss of nutrients (Woolford, 1990). Barley and other high moisture grain silages are prone to spoil rapidly when exposed to air (McAllister et al., 1995; Woolford, 1985). To improve the aerobic stability of these grains, methods to increase the concentration of propionic acid (because of its antifungal properties) in silages have been studied (Woolford, 1975). For example, Higginbotham et al. (1998) used a biological approach by inoculating forage with bacteria capable of producing propionic acid (Propionibacteria). However, these bacteria have difficulty surviving the ensiling process. The direct method of adding propionic acid to silages has resulted in more consistent improvements in aerobic stability (Kung et al., 1998, 
2000 ), but the effects of adding this acid to forage that is or has been exposed to excessive amounts of air before ensiling has not been well studied.

The objective of this study was to compare the effects of delayed ensiling on silage fermentation. Effects of time of application of a buffered propionic acid-based additive on fermentation, aerobic stability, and nutritive value of these silages were also investigated.

\section{MATERIALS AND METHODS}

Spring barley (Hordeum vulgare) was cut at the early dough stage of maturity and allowed to wilt for approximately $8 \mathrm{~h}$. Wilted forage $(9.5 \pm 0.8 \mathrm{~kg})$ was chopped to a theoretical length of $0.95 \mathrm{~cm}$ and treated with nothing (C), or with $0.1 \%$ of a buffered propionic acid-based additive (KI-112; Kemin Industries, Des Moines, IA) (KI), and ensiled immediately in quadruplicate 20-L macro silos (27-cm width $\times 36$-cm height). Portions of the chopped forage (100 kg), untreated (CDF) and treated (KI-DO), were left in loose piles on a clean concrete floor in a barn for $24 \mathrm{~h}$ before being packed into silos. Another portion of the untreated forage exposed to air for $24 \mathrm{~h}$ was also treated with $0.1 \% \mathrm{KI}$ (KI-D24) just before ensiling. Empty and full weights of silos were recorded, and silos were stored in the dark at ambient temperatures ranging between 18 and $25^{\circ} \mathrm{C}$. The four silos for each treatment were opened after 60 $\mathrm{d}$ of ensiling.

The DM content of fresh forage was determined by drying (70 to $75 \mathrm{~g}$ ) in a forced-air oven at $60^{\circ} \mathrm{C}$ for 48 h. After drying, forage samples were ground through a Wiley Mill (1-mm screen; Arthur H. Thomas, Philadelphia, PA) and analyzed for laboratory $\mathrm{DM}\left(100^{\circ} \mathrm{C}\right.$ oven for $24 \mathrm{~h}$ ). Neutral detergent fiber was analyzed by using sulfite and amylase (Van Soest et al., 1991) and ADF by the procedure of Roberston and Van Soest (1981). Total nitrogen was determined after total combustion (LECO Corporation, CNS 2000 Analyzer; St. Joseph, MI) and CP was calculated by multiplying total nitrogen by 6.25 . Starch was analyzed by using the method described by Poore et al. (1993).

Fresh forage $(25 \mathrm{~g})$ was added to a dilution bottle that contained $225 \mathrm{ml}$ of sterile quarter-strength Ringer's solution (Oxoid BR54; Unipath, Basingstoke, UK) and homogenized in a blender for $1 \mathrm{~min}$. After blending, water extracts were filtered through Whatman 54 filter paper (Whatman Inc., Clifton, NJ), acidified with $50 \%$ sulfuric acid, and frozen before analysis of ammonia-N (Weatherburn, 1967) and water-soluble carbohydrates (WSC; Nelson, 1944). Water extracts were analyzed for acetic, propionic, and butyric acids by using a gas chromatograph (Hewlett-Packard 5890 Series II, Hewlett-Packard, Avondale, PA) as described by Kung and
Ranjit (2001). Yeasts and molds were enumerated by pour plating in malt extract agar (Oxoid CM59; Unipath) that had $0.5 \mathrm{ml}$ of $85 \%$ lactic acid added after autoclaving. Plates were incubated at $32^{\circ} \mathrm{C}$ for $48 \mathrm{~h}$. Numbers of colonies on appropriate agar plates were counted at the dilution yielding 30 to 300 colony forming units (cfu) per plate. The $\mathrm{pH}$ of silage extracts was determined within 20 min of homogenization.

After $60 \mathrm{~d}$ of ensiling, silages were processed as described for the fresh forage with the additional determination of lactic acid (D- and L-isomers), ethanol, DM recovery, and in situ DM digestion. L-Lactic acid was analyzed from the acidified water extract by an enzymatic procedure (kit 826-UV; Sigma, St. Louis, MO). For the analysis of D-lactic acid, L-lactic acid dehydrogenase was replaced with a similar amount of D-lactic dehydrogenase (Sigma L-9636). L-Lactic acid (Sigma L-2250) and D-lactic acid (Sigma L-1000) were used as standards for their respective assays. The sums of the L- and D-lactic acids were reported as the total lactate concentration. Ethanol concentrations were determined by using multi-assay vials (Sigma Procedure No. 332-UV) by a procedure for markedly turbid samples. Silo weights were recorded for the full and empty silos to determine DM recovery.

For the determination of in situ ruminal DM, dry barley samples were ground to pass through a $2-\mathrm{mm}$ screen, and $0.5 \mathrm{~g}$ of silage was weighed into Dacron bags $(5 \times 10 \mathrm{~cm}, 53-\mu \mathrm{m}$ pore size; Ankom, Fairport, NY). Bags were heat-sealed and placed in large mesh sacs with $3 \times 5$-mm pores that permitted ruminal fluid to percolate freely. Duplicate bags were placed in the rumen of a fistulated steer fed a diet that was $82.4 \%$ bromegrass hay/grass hay, $8.8 \%$ soybean meal, and $8.8 \%$ dry rolled corn. Bags were incubated for $0,3,6$, $9,12,24,36$, and $48 \mathrm{~h}$. After removal from the steer, bags were washed under running tap water until effluent was clear and then were dried at $55^{\circ} \mathrm{C}$ for $48 \mathrm{~h}$. Dried bags were weighed and DM disappearance was determined.

When silos were opened, silage was mixed well, and a $3-\mathrm{kg}$ sample was returned to its respective silo. No physical packing of the silage took place. A thermocouple wire was placed in the geometric center of each silage mass and temperatures were recorded every 10 min and averaged every 2 -h by a data logger (model no. CR10X; Campbell Scientific, Inc., Logan, UT). A double layer of cheesecloth was placed on the top of each silo to prevent contamination but allowed for penetration of air because silos were incubated between 22 and $23^{\circ} \mathrm{C}$. Aerobic stability was defined as the number of hours before a $2^{\circ} \mathrm{C}$ increase in temperature of the silage mass relative to ambient temperature. Temperatures were recorded for $400 \mathrm{~h}$. 


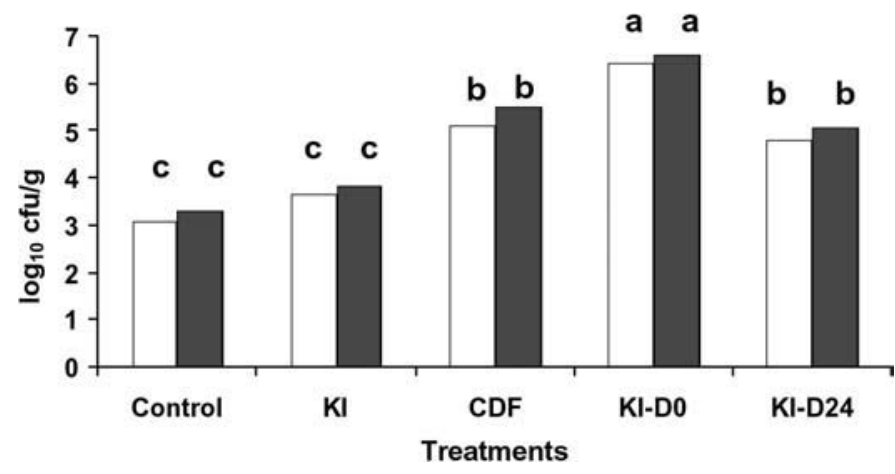

Figure 1. Numbers of yeasts (unshaded bars) and molds (solid bars) on forages. Control = untreated forage, chopped and immediately ensiled, $\mathrm{KI}$ = forage was chopped and treated with an additive based on buffered propionic acid (Kemin Industries, Des Moines, IA) and ensiled immediately, CDF = untreated forage, chopped and exposed to air $24 \mathrm{~h}$ before ensiling, KI-DO = forage, chopped and treated with an additive based on buffered propionic acid and exposed to air for $24 \mathrm{~h}$ before ensiling, KI-D24 = untreated forage, chopped and exposed to air for $24 \mathrm{~h}$, then treated with an additive based on buffered propionic acid before ensiling. $\mathrm{SE}=0.14$ (yeast), $\mathrm{SE}=0.10$ (mold) ${ }^{\mathrm{a}, \mathrm{b}, \mathrm{c}}$ Bars with unlike letters differ $(P<0.05)$.

The chemical composition of forages and silages was analyzed as a completely randomized design by the general linear models procedure of SAS/STAT (1988) with treatment and residual error included in the model. Microbial data were transformed $\left(\log _{10}\right)$ before statistical analysis. The kinetics of ruminal DM disappearance in situ was estimated by the nonlinear regression of SAS/STAT (1988). Means were separated by Tukey's test $(P<0.05$; Snedecor and Cochran, 1980).

\section{RESULTS AND DISCUSSION}

Treatments $\mathrm{C}$ and KI had numbers of yeasts and molds that averaged $3.5 \mathrm{log} \mathrm{cfu} / \mathrm{g}$ and were not different (Figure 1). However, forages that were exposed to air for $24 \mathrm{~h}$ had increased fungal numbers $(P<0.05)$. Of the forages that were exposed to air for $24 \mathrm{~h}$ before ensiling, KI-DO had more $(P<0.05)$ yeasts and molds than CDF and KI-D24. Exposure to air before ensiling also increased $(P<0.05)$ the $\mathrm{pH}$ of forages (Table 1$)$. However, treating forage with the additive at the time of chopping (KI-DO) resulted in the smallest increase in $\mathrm{pH}$, which suggests that the buffered propionic acidbased additive partially reduced the metabolism of some aerobic microorganisms. The concentration of acetic acid was increased in CDF, KI-DO, and KI-D24 compared with $\mathrm{C}$ and $\mathrm{KI}$ and may have been caused by metabolism by enterobacteria in aerated silage. As expected, the buffered propionic acid additive increased the concentration of propionic acid in $\mathrm{KI}(0.27 \%)$ and KID24 (0.33\%) compared with C (undetectable). However, KI-DO had a lower concentration of propionic acid
$(0.10 \%)$ than KI and KI-D24, which suggests that some of the added acid was metabolized or volatilized during exposure to air. The untreated forage $(\mathrm{C})$ had the lowest concentration $(P<0.05)$ of ammonia-N $(0.029 \%)$ compared with other treatments. The KI treatment had more ammonia-N than did C. Increases in ammonia-N because of treatment with buffered propionic acid are a common finding (Kung et al., 1998) because ammonia is usually the principal buffering agent. Thus, higher concentrations of ammonia- $\mathrm{N}$ in silages treated with buffered propionic acid should not be mistaken for excessive proteolysis and deamination. Exposing forage to air before ensiling increased the concentration of ammonia-N $(0.052 \%)$ more than $40 \%$ compared with C. The ammonia-N content of KI-DO and KI-D24, forages exposed to air and treated with buffered propionic acid, were not different from KI. The WSC concentration of C was approximately $3 \%$ and was low compared with concentrations reported in other studies with barley forages (McAllister et al., 1995; Ranjit et al., 1999). After the exposure to air, the WSC concentration decreased $(P<0.05)$ by more than $50 \%$ in treatments CDF, KI-DO, and KI-D24 compared with C. Exposure to air also resulted in forages with greater $(P<0.05)$ concentrations of ADF and NDF but lower concentrations of starch than in fresh forages (C and $\mathrm{KI}$ ). The timing of treatment with buffered propionic acid either at chopping (KI-DO) or after exposure to air (KI-D24) made no difference in forage content of these components. We did not measure DM losses caused by delayed ensiling, but losses of DM during aerobic exposure before ensiling have been reported to be small relative to losses incurred in the subsequent ensiling and storage period (Henderson and McDonald, 1975). Collectively, the reduction in nutritive value and proliferation of yeasts and molds when chopped forage is exposed to air reinforces the recommendation for rapid and tight packing of silos.

The chemical composition of barley silage after $60 \mathrm{~d}$ of ensiling is presented in Table 2. Immediate addition of the buffered propionic acid-based additive to chopped forage (KI and KI-DO) resulted in silage with a higher DM content compared with other treatments, but the reasons for this finding are unknown. DM recovery was not different among treatments but was numerically greater in silages treated with the additive than in untreated silages. In the silage made from forage immediately ensiled, application of the additive (KI) had no effect on fermentation end-products compared with C. Ranjit and Kung (2000) reported similar findings in that low levels of buffered propionic acid generally had no effect on silage fermentation. The $\mathrm{C}$ and $\mathrm{KI}$ treatments were not different in $\mathrm{pH}(<4.0)$, but silages from forages that were exposed to air for $24 \mathrm{~h}$ had $\mathrm{pH}$ values 
Table 1. Chemical (DM basis) composition of barley forage before ensiling.

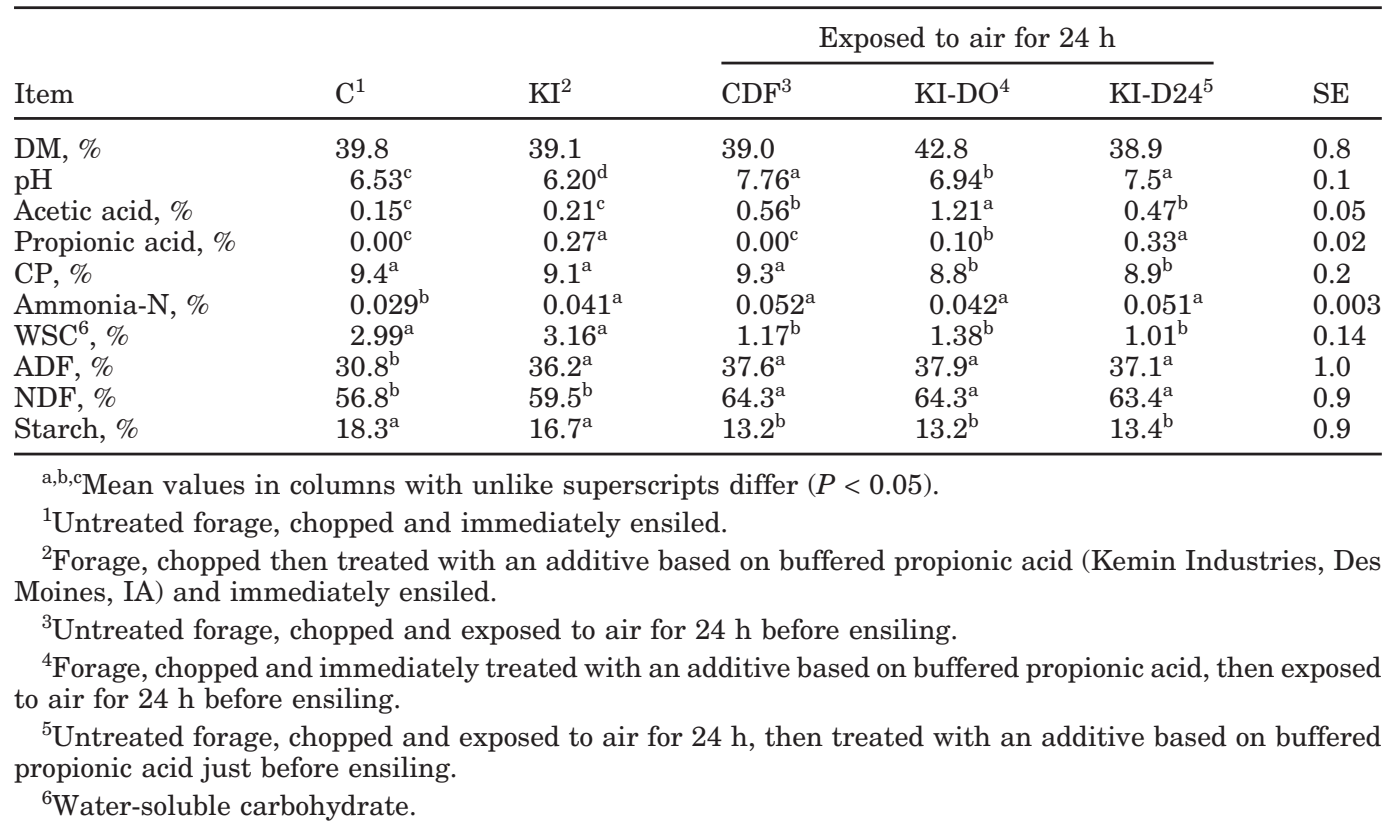

of 4.5 or more. Of these silages, CDF and KI-D24 had higher $(P<0.05) \mathrm{pH}$ than did KI-DO. The residual concentrations of WSC were not different among the treatments. The $\mathrm{C}$ and $\mathrm{KI}$ treatments had an average concentration $(P<0.05)$ of lactic acid of $5.44 \%$ of DM, which is similar to values reported by McAllister et al. (1995) and Ranjit et al. (1999) in barley silages. In the current study, exposure to air before ensiling resulted in silages with lower $(P<0.05)$ concentrations of lactic acid (average, 3.03\%) than did silage from forage ensiled immediately (5.17 to $5.71 \%$ ). Concentration of acetic acid was greatest $(P<0.05)$ in $\mathrm{C}$ and $\mathrm{KI}$ treatments (2.65 and $2.47 \%$, respectively). The CDF and KI-D24 had lower concentrations $(P<0.05)$ of acetic acid $(1.59$ to $1.85 \%$ ) than $\mathrm{C}$, but silage treated with KI-DO had the lowest $(P<0.05)$ concentration of acetic acid $(0.94 \%)$ of all of the silages. Immediate ensiling $(\mathrm{C}$ and $\mathrm{KI})$ resulted in silages with the lowest $(P<0.05)$ concentra-

Table 2. Chemical composition (DM basis) and fungal counts barley silage after $60 \mathrm{~d}$ of ensiling.

\begin{tabular}{|c|c|c|c|c|c|c|}
\hline \multirow[b]{2}{*}{ Item } & \multirow[b]{2}{*}{$\mathrm{C}^{1}$} & \multirow[b]{2}{*}{$\mathrm{KI}^{2}$} & \multicolumn{3}{|c|}{$\begin{array}{l}\text { Forage exposed to air for } 24 \mathrm{~h} \\
\text { before ensiling }\end{array}$} & \multirow[b]{2}{*}{$\mathrm{SE}$} \\
\hline & & & $\mathrm{CDF}^{3}$ & $\mathrm{KI}-\mathrm{DO}^{4}$ & $\mathrm{KI}-\mathrm{D} 24^{5}$ & \\
\hline DM, \% & $36.3^{\mathrm{c}}$ & $38.5^{\mathrm{b}}$ & $36.2^{\mathrm{c}}$ & $40.4^{\mathrm{a}}$ & $37.0^{\mathrm{c}}$ & 0.7 \\
\hline DM recovery, \% & 91.3 & 98.0 & 91.8 & 94.8 & 93.6 & 2.9 \\
\hline $\mathrm{pH}$ & $3.98^{\mathrm{c}}$ & $3.92^{\mathrm{c}}$ & $4.61^{\mathrm{a}}$ & $4.50^{\mathrm{b}}$ & $4.66^{\mathrm{a}}$ & 0.02 \\
\hline $\mathrm{WSC}^{6}, \%$ & 0.98 & 0.63 & 0.56 & 0.70 & 0.64 & 0.11 \\
\hline Lactic acid, \% & $5.71^{\mathrm{a}}$ & $5.17^{\mathrm{a}}$ & $3.31^{\mathrm{b}}$ & $3.03^{\mathrm{b}}$ & $2.75^{\mathrm{b}}$ & 0.22 \\
\hline Acetic acid, \% & $2.65^{\mathrm{a}}$ & $2.47^{\mathrm{a}}$ & $1.85^{\mathrm{b}}$ & $0.94^{\mathrm{c}}$ & $1.59^{\mathrm{b}}$ & 0.18 \\
\hline Propionic acid, \% & $0.01^{\mathrm{c}}$ & $0.10^{c}$ & $0.51^{\mathrm{b}}$ & $0.52^{\mathrm{b}}$ & $0.99^{\mathrm{a}}$ & 0.03 \\
\hline Butyric acid, \% & $0.00^{c}$ & $0.03^{c}$ & $1.65^{\mathrm{a}}$ & $1.63^{\mathrm{a}, \mathrm{b}}$ & $1.76^{\mathrm{a}}$ & 0.02 \\
\hline Ethanol, \% & $0.96^{\mathrm{b}, \mathrm{c}}$ & $0.91^{\mathrm{c}}$ & $1.29^{\mathrm{a}}$ & $1.02^{\mathrm{a}, \mathrm{b}}$ & $1.31^{\mathrm{a}}$ & 0.03 \\
\hline
\end{tabular}

a,b,c,d,e Mean values in columns with unlike superscripts differ $(P<0.05)$.

${ }^{1}$ Untreated forage, chopped and immediately ensiled.

${ }^{2}$ Forage, chopped then treated with an additive based on buffered propionic acid (Kemin Industries, Des Moines, IA) and immediately ensiled.

${ }^{3}$ Untreated forage, chopped and exposed to air for $24 \mathrm{~h}$ before ensiling.

${ }^{4}$ Forage, chopped and immediately treated with an additive based on buffered propionic acid, then exposed to air for $24 \mathrm{~h}$ before ensiling.

${ }^{5}$ Untreated forage, chopped and exposed to air for $24 \mathrm{~h}$, then treated with an additive based on buffered propionic acid just before ensiling.

${ }^{6}$ Water-soluble carbohydrate. 
Table 3. Nutrient content of barley silages (DM basis) after $60 \mathrm{~d}$ of ensiling.

\begin{tabular}{|c|c|c|c|c|c|c|}
\hline \multirow[b]{2}{*}{ Item } & \multirow[b]{2}{*}{$\mathrm{C}^{1}$} & \multirow[b]{2}{*}{$\mathrm{KI}^{2}$} & \multicolumn{3}{|c|}{$\begin{array}{l}\text { Forage exposed to air for } 24 \mathrm{~h} \\
\text { before ensiling }\end{array}$} & \multirow[b]{2}{*}{$\mathrm{SE}$} \\
\hline & & & $\mathrm{CDF}^{3}$ & $\mathrm{KI}-\mathrm{DO}^{4}$ & $\mathrm{KI}-\mathrm{D} 24^{5}$ & \\
\hline $\mathrm{CP}, \%$ & 9.3 & 9.3 & 9.1 & 9.2 & 9.6 & 0.2 \\
\hline Ammonia-N, \% & $0.169^{\mathrm{c}}$ & $0.159^{\mathrm{c}}$ & $0.250^{\mathrm{a}}$ & $0.199^{\mathrm{b}}$ & $0.254^{\mathrm{a}}$ & 0.006 \\
\hline $\mathrm{ADF}, \%$ & $37.2^{\mathrm{b}}$ & $37.7^{\mathrm{b}}$ & $40.6^{\mathrm{a}}$ & $39.8^{\mathrm{a}}$ & $39.9^{\mathrm{a}}$ & 0.7 \\
\hline NDF, \% & $59.7^{\mathrm{c}}$ & $60.7^{b, c}$ & $64.4^{\mathrm{a}}$ & $63.7^{\mathrm{a}}$ & $62.9^{\mathrm{a}, \mathrm{b}}$ & 0.9 \\
\hline Starch, \% & $12.0^{\mathrm{a}}$ & $12.4^{\mathrm{a}}$ & $7.9^{\mathrm{b}}$ & $11.4^{\mathrm{a}}$ & $10.3^{\mathrm{a}}$ & 0.9 \\
\hline \multicolumn{7}{|c|}{${ }^{\mathrm{a}, \mathrm{b}, \mathrm{c}}$ Mean values in columns with unlike superscripts differ $(P<0.05)$. } \\
\hline \multicolumn{7}{|c|}{${ }^{2}$ Forage, chopped then treated with an additive based on buffered propionic acid (Kemin Industries, Des } \\
\hline \multicolumn{7}{|c|}{ Moines, IA) and immediately ensiled. } \\
\hline \multicolumn{7}{|c|}{${ }^{3}$ Untreated forage, chopped and exposed to air for $24 \mathrm{~h}$ before ensiling. } \\
\hline \multicolumn{7}{|c|}{$\begin{array}{l}{ }^{4} \text { Forage, chopped and immediately treated with an additive based on buffered propionic acid, then exposed } \\
\text { to air for } 24 \mathrm{~h} \text { before ensiling. }\end{array}$} \\
\hline $\begin{array}{l}{ }^{5} \text { Untreated fo } \\
\text { propionic acid ju }\end{array}$ & $\begin{array}{l}\text { chopped s } \\
\text { core ensil }\end{array}$ & posed to & $\mathrm{r} 24 \mathrm{~h}$, th & ted with & & \\
\hline
\end{tabular}

tions of propionic acid. Leaving $\mathrm{C}$ and $\mathrm{KI}-\mathrm{DO}$ forage in piles exposed to air for $24 \mathrm{~h}$ contributed to higher $(P<$ 0.05) concentrations of propionic acid, but adding the additive after exposure to air and then ensiling resulted in the highest concentration of propionic acid. In a previous study (Kung et al., 1998), silages treated with buffered propionic acid-based preservatives had final concentrations of propionic acid that were similar to initial applied concentrations. However, in one study (J. Neylon and L. Kung, Jr., unpublished data, University of Delaware, 2000) from our laboratory, a propionic acid-based additive did not improve the aerobic stability of corn silage because initial concentrations of propionic acid were not detectable after the ensiling period. These data suggest that the efficacy of propionic acid preservatives may be partially dependent on their stability during the ensiling process. Future experiments should be conducted to determine what factors can affect the degradation of propionic acid during ensiling and storage. The $\mathrm{C}$ and $\mathrm{KI}$ silages had concentrations of butyric acid of less than $0.05 \%$ of DM, which is an indicator of good fermentation. However, silages from forages exposed to air for $24 \mathrm{~h}$ before ensiling had more than 1.6\% butyric acid. Henderson and McDonald (1975) suggested that exposing chopped forage to air for prolonged periods of time prevented a decrease in silage $\mathrm{pH}$ because aerobic microbes metabolized sugars and there was also an increase in proteolysis. A lack of substrate and high $\mathrm{pH}$ resulted in growth of clostridia, which caused excessive production of butyric acid. Prolonged exposure to air before ensiling has also resulted in high concentrations of butyric acid (McDonald et al., 1991). The concentration of ethanol was higher in CDF and KI-D24 compared with C and KI. Higher concentrations of ethanol are indicative of greater metabolic activity of yeasts.
The CP, ammonia-N, fiber fractions, and starch content of silages are presented in Table 3. The concentration of ammonia-N was higher $(P<0.05)$ in the silages made from forage exposed to air before ensiling ranging from 0.199 to $0.250 \%$ than for $\mathrm{C}(0.169 \%)$ and $\mathrm{KI}$ $(0.159 \%)$. The lower ammonia-N for KI-DO than for CDF or KI-D24 suggests that treatment with propionic acid at time of chopping reduces the negative effects of prolonged exposure to air on the resulting concentration of ammonia- $\mathrm{N}$ in silage. There were no differences in the concentration of $\mathrm{CP}$ among treatments and ranged from 9.1 to $9.6 \%$. Silages from forages that had been exposed to air before ensiling had higher concentrations of NDF and ADF than did C because of a greater loss of the more readily degradable components such as WSC and some proteins. Concentration of starch was not different among C (12.0\%), KI (12.4\%), KI-DO (11.4\%), and KI-D24 (10.3\%). However, CDF contained the lowest concentration (7.9\%) of starch, which may have been because of metabolism by aerobic microorganisms, specifically fungi.

Apparent in situ ruminal DM digestibility is presented in Table 4. Addition of the buffered propionic acid-based additive had no effect on in situ DM digestion of silage that was immediately ensiled. However, exposure to air, before ensiling, resulted in a lower $(P$ $<0.05)$ DM digestibility (64.7\% for CDF vs. $71.7 \%$ for C). The lag time was also longer $(P<0.05)$ for $\mathrm{CDF}$ compared with other silages. Whitlock et al. (2000) reported marked reductions in in vivo nutrient digestion when steers were fed diets that contained various amounts of surface-spoiled silage. These data suggest that the nutritive value of silage can be markedly reduced when the ensiling process is adversely affected by exposure to air. In contrast, the in situ DM digestibility of KI-DO and KI-D24, silages exposed to air but 
Table 4. Apparent in situ DM digestion of barley silages.

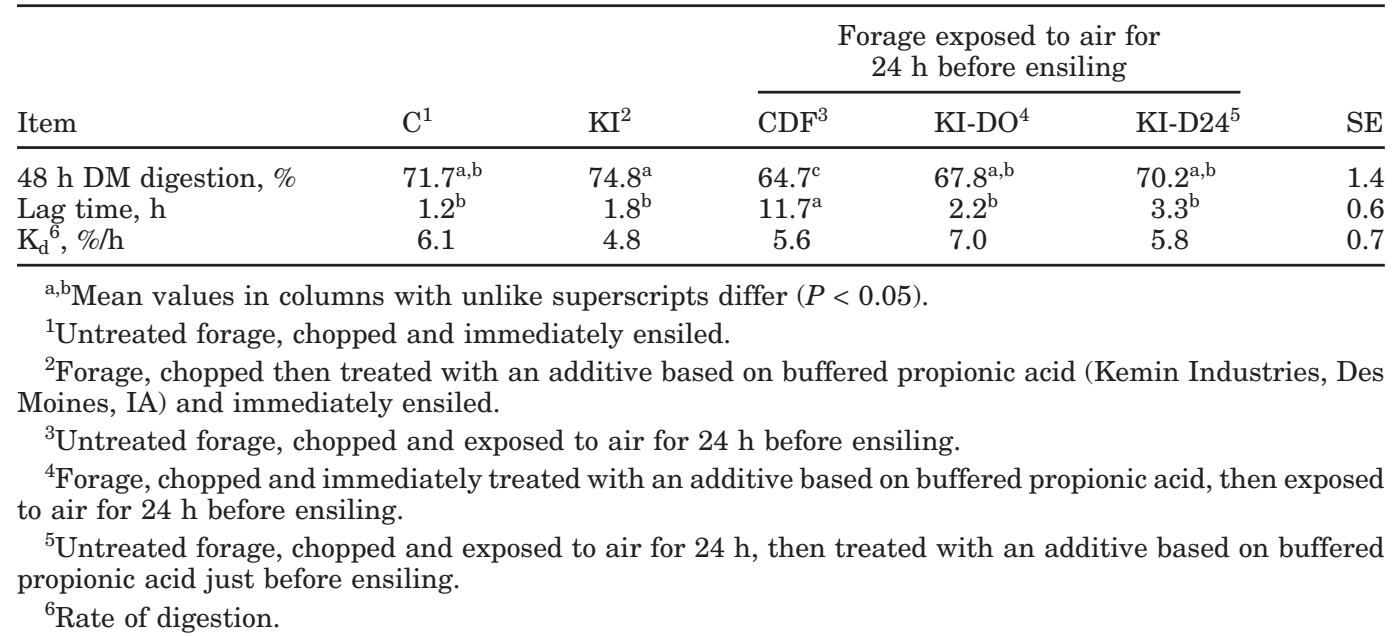

treated with the additive before or at ensiling, were not different from $\mathrm{C}$ and KI. Thus, treatment with the buffered propionic acid additive prevented the negative effects that exposure to air before ensiling had on in situ DM digestibility.

Silages that were chopped and immediately ensiled ( $\mathrm{C}$ and $\mathrm{KI}$ ) were stable when exposed to air for a relatively prolonged period of time ( $>130 \mathrm{~h}$, Figure 2$)$ because numbers of yeasts and molds were less than 2 $\log _{10} \mathrm{cfu} / \mathrm{g}$ (data not shown). In previous studies from our laboratory, untreated corn silage spoiled within 30 to $60 \mathrm{~h}$ after exposure to air, but numbers of residual yeast in those studies were between 4 and $5 \log _{10} \mathrm{cfu} /$ $\mathrm{g}$ (Ranjit and Kung, 2000). Silages from forage exposed

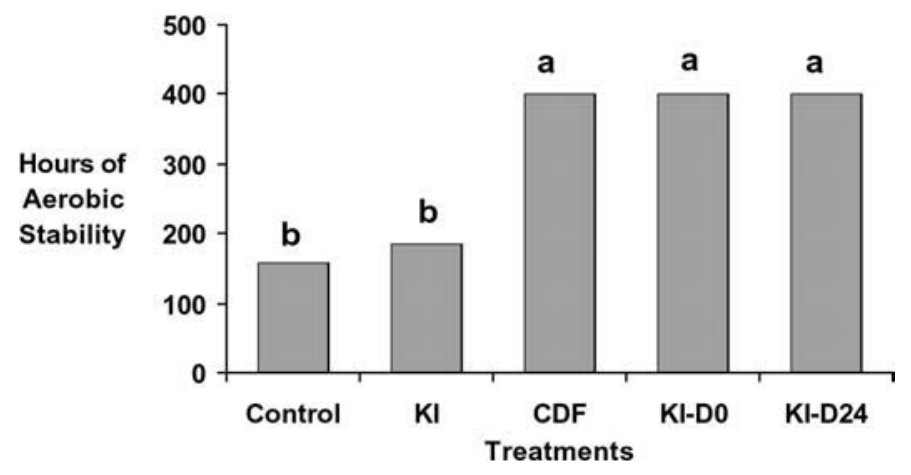

Figure 2. The aerobic stability of barley silages. Control = untreated forage, chopped and immediately ensiled, KI = forage was chopped and treated with an additive based on buffered propionic acid and ensiled immediately, $\mathrm{CDF}=$ untreated forage, chopped and exposed to air $24 \mathrm{~h}$ before ensiling, $\mathrm{KI}-\mathrm{DO}=$ forage, chopped and treated with an additive based on buffered propionic acid and exposed to air for $24 \mathrm{~h}$ before ensiling, KI-D24 = untreated forage, chopped and exposed to air for $24 \mathrm{~h}$, then treated with an additive based on buffered propionic acid before ensiling. $\mathrm{SE}=10$. ${ }^{\mathrm{a}, \mathrm{b}}$ Bars with unlike letters differ $(P<0.05)$. to air before ensiling (CDF, KI-DO, and KI-D24) were stable throughout the entire monitoring period, probably because of the combined effects of high concentrations of butyric acid, propionic acid, and ammonia-N in these silages. Cai et al. (1999) reported that yeasts from deteriorating silage were tolerant to lactic but not butyric acid. Ohyama et al. (1975) also reported that silages with high concentrations of butyric acid were stable when exposed to air and Woolford (1975) reported that this acid had a greater antifungal effect than acetic or propionic acids.

\section{CONCLUSIONS}

When chopped barley forage is exposed to air for a prolonged period of time before ensiling, the number of detrimental microorganisms increases whereas the concentration of fermentable substrate decreases. Collectively, this results in a fermentation that is dominated by clostridia and results in high concentrations of butyric acid and ammonia- $\mathrm{N}$ in the resulting silage. The application of a buffered propionic acid-based additive was unable to stop the shift toward a clostridial fermentation, but if forage was treated before exposure to air, some indices of fermentation quality were not as negatively affected by the exposure to air. Exposure to air before ensiling also reduced in situ DM digestion, but not if silage was treated with a buffered propionic acid additive regardless of timing of the application. These results show that use of a buffered propionic acidbased additive can partially, but not totally, compensate for poor silo management practices. However, rapid filling of silos and achieving adequate packing densities to exclude excessive air should still be high priorities for making excellent quality silage. 


\section{ACKNOWLEDGMENTS}

The authors thank Tony Timko for management of the barley silage at the University of Delaware. We would like to thank Caroline Golt, Alison Whiter, Jeanne Neylon, Christy Taylor, and Janey Lazartic for assistance throughout the study.

\section{REFERENCES}

Cai, Y., Y. Benno, M. Ogawa, and S. Kumai. 1999. Effect of applying lactic acid bacteria isolated from forage crops on fermentation characteristics and aerobic deterioration of silage. J. Dairy Sci. 82:520-526.

Henderson, A. R., and P. McDonald. 1975. The effect of delayed sealing on fermentation and losses during ensilage. J. Sci. Food Agric. 26:653-667.

Higginbotham, G. E., S. C. Mueller, K. K. Bolsen, and E. J. DePeters. 1998. Effects of inoculants containing propionic acid bacteria on fermentation and aerobic stability of corn silage. J. Dairy Sci. 81:2185-2192.

Kung, L., Jr., and N. K. Ranjit. 2001. The effect of Lactobacillus buchneri and other additives on the fermentation and aerobic stability of barley silages. J. Dairy Sci. 84:1149-155.

Kung, L., Jr., J. R. Robinson, N. K. Ranjit, J. H. Chen, and C. M. Golt. 2000. Microbial populations, fermentation end-products, and aerobic stability of corn silage treated with ammonia or a propionic acid-based preservative. J. Dairy Sci. 83:1479-1486.

Kung, L., Jr., A. C. Sheperd, A. M. Samagala, K. M. Endres, C. A. Bessett, N. K. Ranjit, and J. L. Glancey. 1998. The effect of preservatives based on propionic acid on the fermentation and aerobic stability of corn silage and a total mixed ration. J. Dairy Sci. 81:1322-1330.

McAllister, T. A., L. B. Selinger, L. R. McMahon, H. D. Bae, T. J. Lysyk, S. J. Oosting, and K. J. Cheng. 1995. Intake, digestibility and aerobic stability of barley silage inoculated with mixtures of Lactobacillus plantarum and Enterococcus faecium. Can. J. Anim. Sci. 75:425-432.

McDonald, P., N. Henderson, and S. J. E. Heron. 1991. The Biochemistry of Silage. Chalcombe Publications, Marlowe, U.K.
Nelson, N. 1944. A photometric adaptation of the Somogyi method for the determination of glucose. J. Biol. Chem. 153:375-380.

Ohyama, Y., S. Maski, and S. Hara. 1975. Factors influencing aerobic deterioration of silages in chemical composition after opening silos. J. Sci. Food Agric. 26:1137-1147.

Poore, M. H., J. A. Moore, T. P. Eck, R. S. Swingle, and C. B. Theurer. 1993. Effect of fiber source and ruminal starch degradability on site and extent of digestion in dairy cows. J. Dairy Sci. 76:2244-2253.

Ranjit, N. K., and L. Kung, Jr. 2000. The effect of Lactobacillus buchneri, Lactobacillus plantarum, or a chemical preservative on the fermentation and aerobic stability of corn silage. J. Dairy Sci. 83:526-535.

Ranjit, N. K., L. Kung, Jr., J. R. Robinson, and K. K. Kreikemeier. 1999. Inoculation with Lactobacillus buchneri increases the acetate and propionate content of barley silage resulting in improved aerobic stability. J. Anim. Sci. 77(Suppl. 1): 253. (Abstr.).

Robertson, J. B., and P. J. Van Soest. 1981. The detergent system of analysis and its application to human foods. Pages 123-158 in The Analysis of Dietary Fiber in Food. W. P. T. James and O. Theander, eds. Marcel Dekker, New York, NY.

SAS/STAT. 1988. User's Guide, Release 6.03. SAS Inst., Inc., Cary, NC.

Snedecor, G. W., and W. G. Cochran. 1980. Statistical Methods. 6th ed. Iowa State Univ. Press, Ames, IA.

Van Soest, P. J., J. B. Robertson, and B. A. Lewis. 1991. Methods for dietary fiber, neutral detergent fiber, and nonstarch polysaccharides in relation to animal nutrition. J. Dairy Sci. 74:35833597.

Weatherburn, M. W. 1967. Phenol-hypochlorite reaction for determinations of ammonia. Anal. Chem. 39:971-974.

Whitlock, L. A., T. J. Wistuba, M. K. Seifers, R. V. Pope, and K. K. Bolsen. 2000. Effect of level of surface-spoiled silage on the nutritive value of corn silage diets. J. Dairy Sci. 83(Suppl. 1):110. (Abstr.).

Woolford, M. K. 1975. Microbiological screening of straight chain fatty acids (C1-C12) as potential silage additives. J. Sci. Food Agric. 26:219-228.

Woolford, M. K. 1985. The Silage Fermentation. Marcel Dekker, New York, NY.

Woolford, M. K. 1990. The detrimental effects of air on silage. J. Appl. Bacteriol. 68:101-116. 